\title{
PREDICITION OF COMPRESSIVE STRENGTH IN LIGHT-WEIGHT SELF-COMPACTING CONCRETE BY ANFIS ANALYTICAL MODEL
}

\author{
B. VAKHSHOURI ${ }^{1}$, S. NEJADI ${ }^{2}$
}

\begin{abstract}
Light-weight Self-Compacting Concrete (LWSCC) might be the answer to the increasing construction requirements of slenderer and more heavily reinforced structural elements. However there are limited studies to prove its ability in real construction projects. In conjunction with the traditional methods, artificial intelligent based modeling methods have been applied to simulate the non-linear and complex behavior of concrete in the recent years. Twenty one laboratory experimental investigations on the mechanical properties of LWSCC; published in recent 12 years have been analyzed in this study. The collected information is used to investigate the relationship between compressive strength, elasticity modulus and splitting tensile strength in LWSCC. Analytically proposed model in ANFIS is verified by multi factor linear regression analysis. Comparing the estimated results, ANFIS analysis gives more compatible results and is preferred to estimate the properties of LWSCC.
\end{abstract}

Keywords: ANFIS, regression analysis, light-weight self-compacting concrete, compressive strength, elasticity modulus, splitting tensile strength

\section{INTRODUCTION}

The early evaluation of hardened concrete properties and predicting the relationships between the mechanical properties of concrete is very important. The problem is that following the hardening process, the quality and mechanical properties cannot improve.

\footnotetext{
${ }^{1}$ PhD., University of Technology Sydney, Faculty of Civil and Environmental Engineering, Sydney, NSW, Australia, e-mail: Behnam.vakhshouri@student.uts.edu.au

${ }^{2} \mathrm{PhD}$., University of Technology Sydney, Faculty of Civil and Environmental Engineering, Sydney, NSW, Australia, e-mail: shami.nejadi@uts.edu.au
} 
Numerous complex failure mechanisms may happen in brittle heterogeneous solids like concrete containing several flaws and cavities [1]. The most identified specific for quality characterization and concrete classification is Compressive strength (CS) [2] that is essential to express other mechanical properties of concrete.

Many approaches have been developed to estimate the compressive strength of concrete related to other hardened properties (Chen et al.2003, Han et al. 2003, Gupta et al.2006, Peng et al. 2009, Sobhani et al. 2010, Atici 2011) [3], however in the case of LWSCC there is almost no study to predict CS from fresh or hardened properties. Along with the traditional methods, fuzzy logic and neural networks are increasingly used to achieve the specification of relationships among several variables in a complex dynamic process, accomplish mappings and to control non-linear systems to a magnitude not conceivable by linear systems.

Adaptive Neuro-Fuzzy Inference System (ANFIS), which has the benefits of both neural network and fuzzy systems, is particularly useful in the engineering applications where classical approaches fail or they are too complicated to be used [4]. Nataraja et al. (2006) [5] designed A Fuzzy-Neuro model for mix design of conventional concrtete. Tesfamariam and Najjaran (2007) [6] used ANFIS model to estimate CS from mix design. Mahmut Bilgehan (2011) [7] compared the predicted concrete strength estimation from neural network and neuro-fuzzy modeling approaches. Tanyildizi and Qoskun (2007) [8] used fuzzy logic model to predict the CS of lightweight concrete made with scoria aggregate and fly ash. Uyunoglu and Unal (2006) [9] proposed a new approach to determination of CS of fly ash concrete using fuzzy logic. Yang et al. (2005) have studied on Concrete strength evaluation based on fuzzy neural networks. [10] Vakhshouri and Nejadi (2014) [3] compared the developed models of CS in high strength concrete by applying various features in ANFIS. The majority of above mentioned studies verify the adequacy of fuzzy system and neural networks to predict the mechanical properties of different types of concrete.

\section{Light-Weight Self- Compacting CONCRETE}

Excellent adaptability, availability and economy aspects, make concrete the world's most broadly used construction material. Despite all benefits related to the use of concrete, considerable self-weight of concrete compared to other construction materials and workability problems limit its use in some structures. [11] Dense concrete increases the mass of the structures and consequently the related forces and hazards. 
In recent decades, utilizing the mineral and chemical admixtures in concrete technology has introduced several changes in formulation and mix design to make the concrete workable, stronger and durable. [12] LWSCC as a combination of Light Weight Concrete (LWC) and SelfCompacting Concrete (SCC) is a result of advances in concrete technology to come over the limits in concrete structures. Using LWC may result in smaller dimension and lighter elements that both decrease the total weight of the structure and the lateral loads that is a major problem in most parts of the world. $[12,13]$ It is naturally utilized in structures for which major part of the total load is due to dead load weight of concrete. Consequently, the construction cost can be protected when applied to structures such as long span bridge and high rise buildings [14]. In addition, better thermal insulation; better reinforcing steel-concrete bond, durability performance, tensile strain capacity, and fatigue resistance make it superior to normal weight concrete [12, 14]. In conjunction with the density of concrete; workability, strength, and durability are major considerations in concrete application in construction industry. While the strength and durability are related to the hardened concrete, the workability is related to the fresh concrete [15].

Nowadays SCC is inevitable solution to most workability problems. SCC as new type of concrete which has the capabilities of flowing easily, filling the formwork and making a full compaction under its own weight, eliminates the vibration process, improves the environmental consideration and reduces the labor works. Beside, SCC has proven advantages enhancing construction productivity, reducing the overall cost of the structure, achieving sustainable characteristics, increasing the practically allowable reinforcement rate, and increasing the construction rate and overall quality of the cast structures [16]. There are wide range of publications about LWC with different light weight aggregates and mix proportions. However SCC is completely new topic in construction industry that is rapidly growing in research and real project applications in last decade. Since LWSCC is combination of two materials which one part is not pretty investigated, it needs much more investigations.

\section{RESEARCH SIGNIFICANCE}

LWSCC could be an excellent solution to decrease the structure weight and ease of construction $[17,18]$; however its mechanical properties are not completely understood in the literature to use in real construction projects. LWSCC is combination of LWC and SCC and contains the advantages and limits of both types of concrete. Mechanical properties of LWSCC are very sensitive to its mix proportions and the relationship between the fresh properties and mechanical properties is not 
predictable like other types of concrete. Due to complicated nature and nonlinear behavior of LWSCC and large number of effecting parameters, traditional methods may not be able to give reasonable relationships between different properties of LWSCC; though ANFIS has proven its ability to establish the relationships between parameters in complicated engineering systems and materials.

The main objectives of this study are:

- Systematic evaluation of the experiments conducted by researches in different parts of the world. Since LWSCC is a novel material in construction industry, comprehensive collection of data so far and giving comparisons will be a major start point for upcoming researchers and its application in real projects.

- Developing analytical models between CS, Elasticity Modulus (EM) and Splitting Tensile Strength (STS) of LWSCC in ANFIS

- Verifying the analytical models with multi-factor linear regression analysis, statistical coefficients and experimental data in the literature

The general form of the multi-factor linear regression analysis is presented in Eq. (3.1).

$$
\mathrm{y}=\mathrm{f}\left(\beta_{\mathrm{i}} \mathrm{x}_{\mathrm{i}}\right)=\beta_{1}+\beta_{2} \mathrm{x}_{2}+\beta_{3} \mathrm{x}_{3}+\ldots+\beta_{\mathrm{n}} \mathrm{x}_{\mathrm{n}}
$$

where: $y, f, \beta_{i}$ and $x_{i}$ are the dependent variable, linear function, constant coefficients and the dependent variables of the relation respectively.

\section{DATABASE FOR FRESH AND HARDENED PROPERTIES OF LWSCC}

Resultant data of published experimental investigations is an effective tool to propose and verification of new models and comparing the actual and predicted values. Despite efficiency of experimental data from different sources, using them can be problematic owing to: a) insufficient information concerning the exact composition of the concrete mixes; b) different size and number of the specimen, curing condition, and testing methodology; and (3) extracting real data of experimental results from graphs and diagrams.

The collected experimental database of this study is mainly from papers presented at conferences and published articles on LWSCC. The investigated database in this study contains the empirical data of CS, EM and STS. In addition to clarify the wide variety of component materials in mix design of LWSCC, Table 1 presents information about the composition of the mixes, type 
of chemical admixture (plasticizer and air entraining agent), type of fine and coarse aggregate, filler type and cement type. In addition to the references in Table 1, mechanical properties of LWSCC from experiments of Pons et al. (2007) [19], Suresh Babu et al. (2008) [20] and Gencel et al. (2011) [21] are included in the database of models.

\section{ARCHITECTURE OF ANFIS MODELING}

Fuzzy systems are particularly useful in the engineering applications where classical approaches fail or they are too complicated to be used. ANFIS is a class of adaptive networks, which has the advantages of ANN and linguistic interpretability of Fuzzy Inference Systems (FIS) [22, 23]. Application of ANFIS was first proposed by Jang (1993). Ozel (2011) [24] used ANFIS to predict the CS of high performance conventional concrete from fresh concrete properties. Sadrmomtazi et al. (2013) [25] applied ANFIS analysis to study the relation between CS of lightweight concrete and mixing proportion. Sobhani et al. (2010) [26] applied ANFIS model to predict CS of no-slump concrete and found acceptable results comparing with regression analysis and neural network models.

Table 1. Data base for mix design of LWSCC

\begin{tabular}{|c|c|c|c|c|c|c|c|c|c|}
\hline \multirow{3}{*}{$\underset{\mathbb{Q}}{\Omega}$} & \multicolumn{4}{|c|}{ CA } & \multirow{3}{*}{ LWCA } & \multirow{2}{*}{\multicolumn{2}{|c|}{ NWA }} & \multirow{3}{*}{ Cement } & \multirow{3}{*}{ Filler } \\
\hline & \multicolumn{2}{|c|}{ SP } & \multicolumn{2}{|l|}{ AEA } & & & & & \\
\hline & Type & $\begin{array}{c}\text { Volume } \\
\text { Kg/m3 }\end{array}$ & Type & $\begin{array}{l}\text { Volume } \\
\mathrm{Kg} / \mathrm{m3}\end{array}$ & & Fine & Coarse & & \\
\hline 27 & PCAE & $\begin{array}{c}1.5-1.8 \% \\
\text { of cement } \\
\text { weight } \\
\end{array}$ & & & $\begin{array}{c}\text { artificial } \\
\text { LWA }<15 \mathrm{~mm}\end{array}$ & NRS & CLS $<15 \mathrm{~mm}$ & $\mathrm{PC}$ & FA \\
\hline 10 & $\begin{array}{l}\text { PCB } \\
\text { Eucon } \\
\text { SPJ }\end{array}$ & $\begin{array}{c}3-6 \\
\text { floz/cwt }\end{array}$ & $\begin{array}{c}\text { DARAVAIR } \\
1000, \text { AIR MIX } \\
250 \text { and AIR } 30\end{array}$ & $\begin{array}{c}3.2-4 \\
\text { floz/cwt }\end{array}$ & $\begin{array}{l}\text { crushed granite } \\
\text { from Vulcan mine } \\
\text { material }\end{array}$ & NRS & & $\begin{array}{c}\text { Type III } \\
\text { and Class } \\
\text { C Boral } \\
\text { cement }\end{array}$ & $\begin{array}{l}\text { SF, } \\
\text { FA }\end{array}$ \\
\hline 28 & PCB & 3.3 & VRB & 0.2 & $\mathrm{ES}<9.5 \mathrm{~mm}$ & $\mathrm{NRS}<4.75 \mathrm{~mm}$ & & CEM I & $\begin{array}{c}\text { FA } \\
\text { class } \\
\text { F } \\
\end{array}$ \\
\hline 29 & NLSB & $2-26$ & & & $\begin{array}{l}\text { Manufactured with } \\
\text { sintering fine } \\
\text { sediment excavated } \\
\text { from reservoir } \\
<13 \mathrm{~mm} \\
\end{array}$ & $\begin{array}{l}\text { Crushed } \\
\text { Sand }\end{array}$ & & $\begin{array}{l}\text { CEM I } \\
-\mathrm{C} 150\end{array}$ & $\begin{array}{c}\text { FA } \\
\text { class } \\
\text { F }\end{array}$ \\
\hline 30 & MB & $2.97-7.32$ & N.G ${ }^{*}$ & $\begin{array}{l}0.106- \\
1.203\end{array}$ & & $\mathrm{NRS}<2 \mathrm{~mm}$ & $\begin{array}{c}\text { Gravel }<8, \\
\text { Quartzite } \\
\text { sandstone 8-16 } \\
\text { mm }\end{array}$ & & $\begin{array}{l}\text { SF, } \\
\text { LSP }\end{array}$ \\
\hline 31 & PCB & $1.5 \%$ & N.G. & $0.4 \%$ & & $\begin{array}{l}\text { finely ground } \\
\text { limestone, } \\
\text { NRS }<4 \mathrm{~mm}\end{array}$ & & & \\
\hline 32 & $\begin{array}{l}\mathrm{N} . \\
\mathrm{G} .\end{array}$ & 11.86 & N.G. & 0.6 & $\begin{array}{c}\text { Aggregate of } \\
\text { Carolina Stalite } \\
\text { Company }\end{array}$ & $\mathrm{NRS}<2 \mathrm{~mm}$ & & $\mathrm{PC}$ & FA \\
\hline 33 & N.G. & $\begin{array}{c}7.5 \\
\text { floz/cwt }\end{array}$ & N.G. & $\begin{array}{c}0.3 \\
\text { floz/cwt }\end{array}$ & $\mathrm{EC}<20 \mathrm{~mm}$ & NRS & & $\mathrm{PC}$ & N.G. \\
\hline 3 & PCB & $4.9-1.1$ & Not given & $\begin{array}{c}2.88- \\
6.09\end{array}$ & $\begin{array}{c}\text { Pumice } \\
4-8,8-16 \mathrm{~mm}\end{array}$ & $\begin{array}{l}\text { Crushed sand } \\
(\mathrm{SSD})<5 \mathrm{~mm}\end{array}$ & N.G $5-15 \mathrm{~mm}$ & $\begin{array}{c}\text { CEM I } \\
42.5\end{array}$ & $\begin{array}{l}\text { FA, } \\
\text { LSP }\end{array}$ \\
\hline
\end{tabular}


Table 1. Data base for mix design of LWSCC - continued

\begin{tabular}{|c|c|c|c|c|c|c|c|c|c|}
\hline \multirow{3}{*}{ 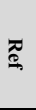 } & \multicolumn{4}{|c|}{ CA } & \multirow{3}{*}{ LWCA } & \multirow{2}{*}{\multicolumn{2}{|c|}{ NWA }} & \multirow{3}{*}{ Cement } & \multirow{3}{*}{ Filler } \\
\hline & \multicolumn{2}{|c|}{ SP } & \multicolumn{2}{|l|}{ AEA } & & & & & \\
\hline & Type & $\begin{array}{l}\text { Volume } \\
\mathrm{Kg} / \mathrm{m} 3\end{array}$ & Type & $\begin{array}{l}\text { Volume } \\
\mathrm{Kg} / \mathrm{m} 3\end{array}$ & & Fine & Coarse & & \\
\hline 34 & N.G. & $7.3-15.1$ & & & $\begin{array}{c}\text { dredged silt from } \\
\text { reservoirs in } \\
\text { southern } \\
\text { Taiwan }<9.5 \mathrm{~mm} \text {, } \\
12.7 \mathrm{~mm} \\
\end{array}$ & $\mathrm{NRS}<2.38 \mathrm{~mm}$ & & CEM I & FA, slag \\
\hline 11 & PCB & $\begin{array}{l}0.7-1.3 \\
\% \text { of } \\
\text { cement } \\
\text { weight }\end{array}$ & N.G. & $\begin{array}{l}0.005 \% \\
\text { of } \\
\text { cement } \\
\text { weight }\end{array}$ & $\begin{array}{c}\mathrm{LC} 1<20 \mathrm{~mm} \\
\text { By rhyolite fine } \\
\text { powder, } \\
\mathrm{LC} 2<20 \mathrm{~mm} \text { by } \\
\text { with wastes } \\
\text { (screening } \\
\text { sludges) } \\
\end{array}$ & $\begin{array}{l}\text { local } \\
\text { NRS }\end{array}$ & $\begin{array}{c}\text { CLS } \\
<20 \mathrm{~mm}\end{array}$ & $\mathrm{PC}$ & N.G. \\
\hline 35 & PCEP & $\begin{array}{c}4.675- \\
4.95 \\
\end{array}$ & & & $\begin{array}{c}\text { Leca } 4.75-9.5 \\
\mathrm{~mm}\end{array}$ & $\mathrm{NRS}<4.75 \mathrm{~mm}$ & & CEM II & $\begin{array}{c}\text { LSP and } \\
\text { SF }\end{array}$ \\
\hline 36 & $\begin{array}{l}\text { ADVA } \\
405, \\
408\end{array}$ & $\begin{array}{c}\text { 15-26 } \\
\text { floz/cwt }\end{array}$ & ADVA 575 & $\begin{array}{c}5-11 \\
\text { floz/cwt }\end{array}$ & $\mathrm{EC}, \mathrm{ES}$ & NRS & CLS & $\begin{array}{l}\text { CEM I in } \\
\text { SCC } \\
\text { CEM III in } \\
\text { LWSCC }\end{array}$ & FA \\
\hline 14 & N.G. & $\begin{array}{l}17.18- \\
19.02\end{array}$ & & & $\begin{array}{c}\text { LECA from EC } \\
0-3,3-10 \mathrm{~mm}\end{array}$ & $\begin{array}{c}\mathrm{NRS}<4.75 \\
\mathrm{~mm}\end{array}$ & $\begin{array}{c}\text { Natural } \\
\text { gravel } \\
<10 \mathrm{~mm} \\
\end{array}$ & CEM II & SF, LSP \\
\hline 12 & PCAE & $5.3-6.4$ & & & $\begin{array}{c}\text { Coarse cold- } \\
\text { bonded FA } \\
4-16 \mathrm{~mm} \\
\end{array}$ & $\begin{array}{c}\text { Mix of CLS } \\
\text { \&NRS } \\
<5 \mathrm{~mm} \\
\end{array}$ & & $\begin{array}{l}\text { CEM I } \\
42.5 \mathrm{R}\end{array}$ & $\begin{array}{l}\text { SF, FA } \\
\text { class F }\end{array}$ \\
\hline 18 & N.G. & $6.5-7.5$ & $\begin{array}{l}\text { SIKA Viscocrete } \\
\text { modified } \\
\text { polycarboxylate } \\
\text { copolymers }\end{array}$ & $4-10$ & $\begin{array}{c}\text { Pumice } \\
4.8-19 \mathrm{~mm}\end{array}$ & $\begin{array}{c}\text { NRS } \\
<9.6 \mathrm{~mm}\end{array}$ & $\begin{array}{c}\text { CLS } \\
<19 \mathrm{~mm}\end{array}$ & $\begin{array}{l}\text { PCC) } \\
\text { Indonesian } \\
\text { Standard } \\
\text { (SNI) 15- } \\
7064-2004\end{array}$ & $\begin{array}{c}\text { FA, } \\
\text { Indocement } \\
\text { TBK }\end{array}$ \\
\hline 17 & PCB & $\begin{array}{c}0.6- \\
1.1 \% \text { of } \\
\text { fine gg. } \\
\text { weight }\end{array}$ & & & $\begin{array}{l}\text { Two Iberian EC: } \\
\text { Leca from } \\
\text { Portugal and } \\
\text { Arlita (Spain) }\end{array}$ & NRS & $\begin{array}{c}\text { CLS } \\
<12.5 \mathrm{~mm}\end{array}$ & $\begin{array}{l}\text { CEM I } \\
42.5 \mathrm{R}\end{array}$ & $\begin{array}{c}\text { FA (Pego } \\
\text { thermoelectric } \\
\text { power plant) }\end{array}$ \\
\hline 37 & PCEP & 1.06 & N.G. & $\begin{array}{l}0.163- \\
2.272\end{array}$ & $\begin{array}{c}\text { Pumice } \\
0-4,4-8 \text { and } \\
8-16 \mathrm{~mm}\end{array}$ & NRS $0-4 \mathrm{~mm}$ & & $\begin{array}{c}\text { CEM II } \\
42.5 \mathrm{~N}\end{array}$ & $\begin{array}{c}\text { Pumice, LSP, } \\
\text { SF }\end{array}$ \\
\hline 38 & PCAE & $2.4-10.2$ & $\begin{array}{l}\text { Oil alcohol and } \\
\text { ammonium salt } \\
\text { based }\end{array}$ & $1.4-3.9$ & $\begin{array}{c}\text { Pumice } \\
4-8,4-16 \mathrm{~mm}\end{array}$ & $\mathrm{NRS}<4 \mathrm{~mm}$ & $\begin{array}{c}\text { CLS } \\
4-16 \mathrm{~mm}\end{array}$ & $\begin{array}{c}\text { CEM I } 42.5 \\
\text { R }\end{array}$ & $\begin{array}{c}\text { industrial } \\
\text { waste of } \\
\text { olivine } \\
\text { powder }\end{array}$ \\
\hline 39 & $\begin{array}{l}\text { Liquid } \\
\text { PCAE }\end{array}$ & $6-7.28$ & & & $\begin{array}{c}\text { Liapor, EC } \\
\text { granules } \\
0-2,1-8 \mathrm{~mm}\end{array}$ & CLS $0-4 \mathrm{~mm}$ & & $\mathrm{PC}$ & $\begin{array}{l}\text { SF,FA, } \\
\text { recycled } \\
\text { concrete } \\
\text { powder }\end{array}$ \\
\hline 40 & PCB & 3.3 & SSA & & Lytag 4-14 mm & $\mathrm{NRS}<600 \mu \mathrm{m}$ & $\begin{array}{l}\text { Crushed } \\
\text { Granite } \\
<20 \mathrm{~mm}\end{array}$ & $\begin{array}{l}\text { CEM I } \\
42.5 \mathrm{~N}\end{array}$ & $\begin{array}{c}\text { PFA, } \\
\text { GGBS, LSP }\end{array}$ \\
\hline
\end{tabular}

Chemical Admixture (CA): Super plasticizer (SP): Poly Carboxylate Based (PCB), Melamine based (MB), Poly Carboxylic Ether Polymer (PCEP), Poly Carboxylic Acid Ether (PCAE), and Naphthalene Lingo-Sulfonate Based (NLSB).

Air Entraining Agent (AEA): Sodium Sulphate Activator (SSA), Vinsol resin based (VRB).

Light weight coarse aggregate (LWCA): Expanded Clay (EC), Expanded Shale (ES).

Normal Weight Aggregate (NWA): Crushed Lime Stone (CLS), Natural River Sand (NRS).

Cement: Portland cement (PC), Portland cement type I and II (CEMI, CEMII).

Fillers: Fly Ash (FA), Limestone powder (LSP)., Silica fume (SF), Pulverised fuel ash (PFA), Ground Granulated Blast furnace Slag (GGBS).

* Not Given (N.G.) in Table 1 indicates where there is no information and the blank means the material is not used in that case study. 
Applying different features in ANFIS to input data and processing steps to classify, normalization and optimization of data and iteration and error calculations give sometimes completely different results.

Comparing all features in ANFIS architecture, the Sugeno type Fuzzy Inference System (FIS), bell shaped distribution of data called here as membership function (gbellmf) and hybrid optimization method with 2500 epochs are applied to get the best results from the ANFIS model with the minimum error in training and testing process of the data.

Hybrid optimization method is a combination of the least-squares and back-propagation gradient descent methods. In conjunction with the classification of data to select the training and testing data, this method is reliable enough to refine the data to reach the minimum error.

The developed ANFIS model to predict a single output from combination of two inputs in this study is shown in general form of Fig. 1.

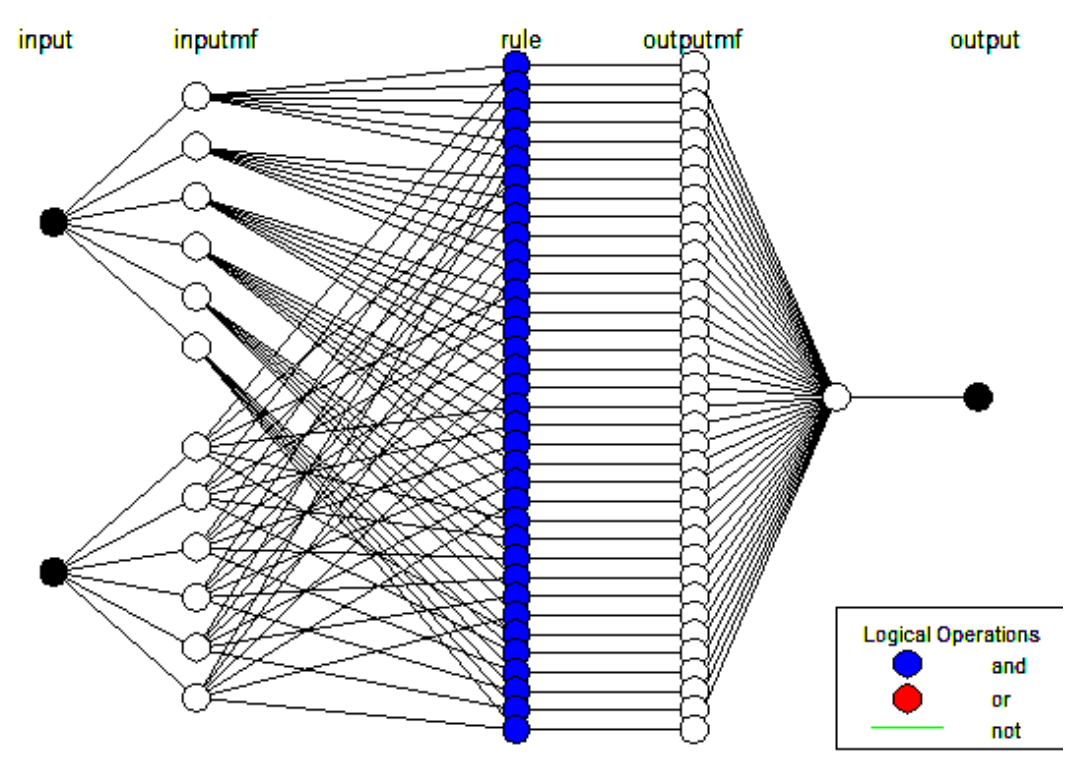

Fig. 1. Architecture of simulated model in ANFIS

The relationship between compressive strength as output with two input data of modulus of elasticity and splitting tensile strength in ANFIS is presented in Fig. 2. 


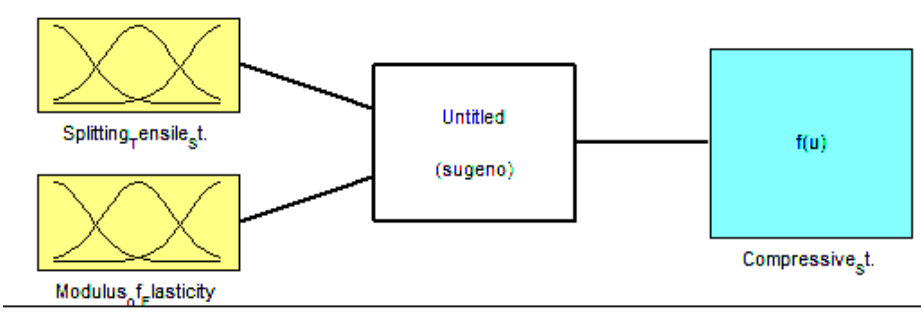

Fig. 2. General form of ANFIS operation between input and output data

According to Fig. 2, the combination of two input data is supposed by "and" rule, in other words, "if STS and EM then CS" rule has been applied to get the desired target from input dataset.

ANFIS takes sets of data as training and testing data and applies logical operations of if-then rules to establish a relationship between input and output data. Established relationship in training stage is evaluated by testing data. The minimum error in testing process concludes the most compatible relationship between the input and output data. Figs. $3(\mathrm{a}, \mathrm{b})$ illustrate the distribution of STS and EM data as two sets of input data in six input mf plots to get the compressive strength as output data. The applied if-then fuzzy rules in different steps to establish a relationship between input and output data by bell shape membership function are presented in Fig. 4.

(a)
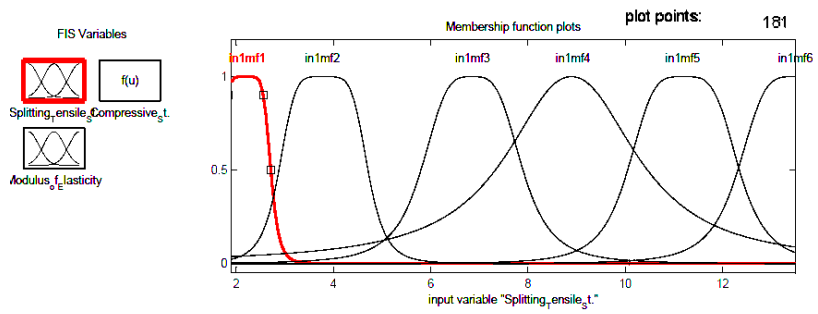

(b)
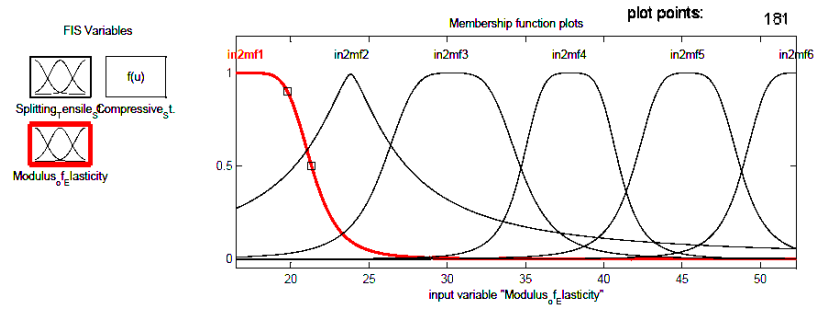

Fig. 3. mf plots of a) STS and b) EM in training of data to establish the fuzzy model 


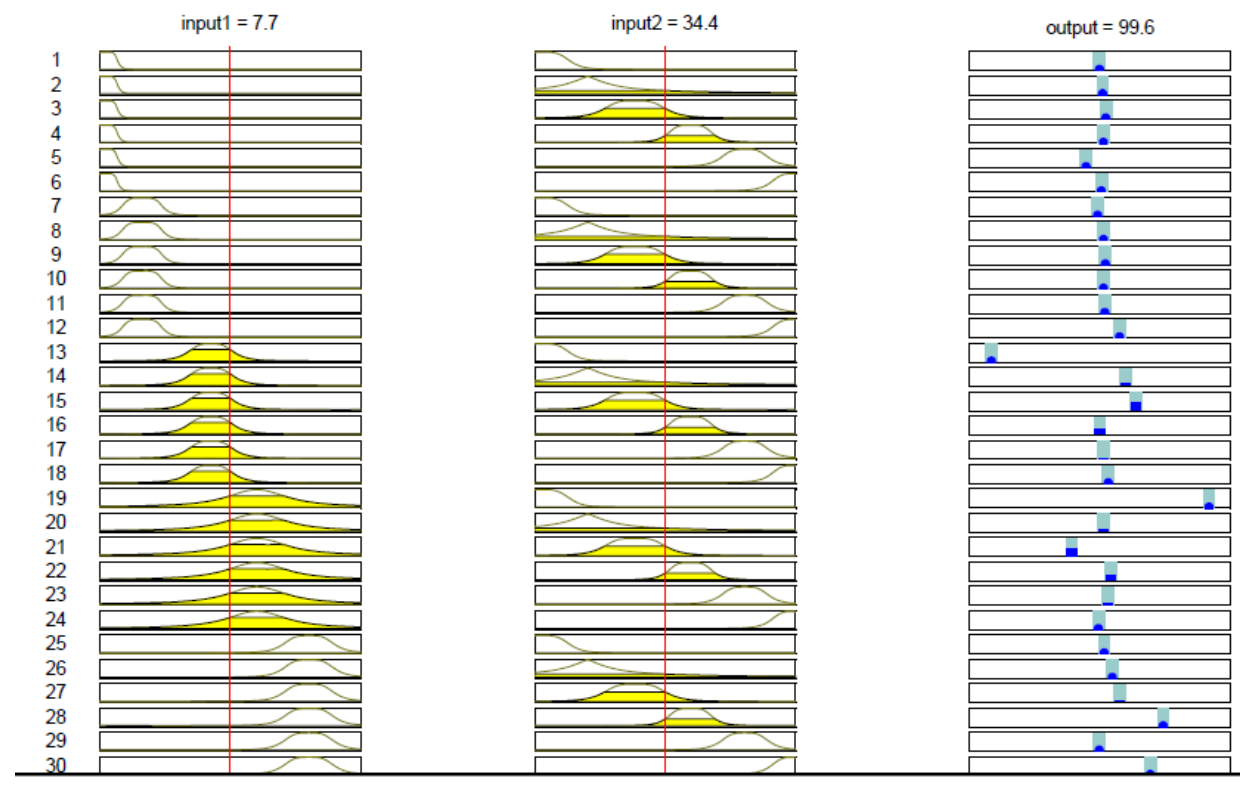

Fig. 4. Reasoning scheme (if-then rules; if input 1 and input 2 then output) of NAFIS with bell shaped $\mathrm{mf}$

\section{PREFERENCES AND PROCESSING OF DATA}

The ratio of number of training data to testing data is 4 , i.e. $80 \%$ of whole data are selected as training data and the remaining $20 \%$ as testing data. To enhance the accuracy of the FIS model and to avoid unexpected errors during the training and testing process in ANFIS, wide range and quantity of data are imported in the model.

In addition, the total data are classified in some ranges and a test data is selected from each range to ensure that the selected test data could be a reliable representative for its range.

As shown in Fig. 5, by applying the above mentioned preferences, the extreme points and distribution shape of testing data is similar to training data. 


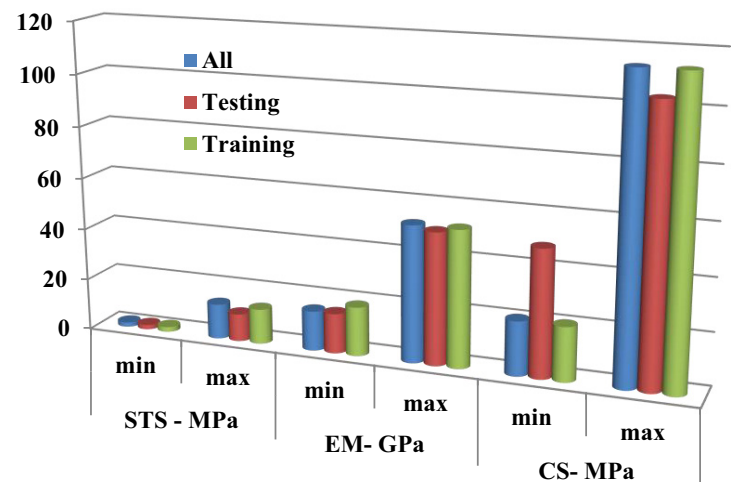

Fig. 5. Testing and training data range in ANFIS model and regression analysis

\section{EVALUATION FACTORS}

To evaluate the performance of the developed models in ANFIS and to compare the predicted results with the multi factor regression analysis, statistical parameters of Euclidean Norm (EN) in Eq. (2) and Square of the Pearson Product Moment Correlation Coefficient (SPPMCC) in Eq. (3) are used.

$$
\mathrm{EN}=\mathrm{f}\left(\mathrm{x}_{\text {predict }}, \mathrm{x}_{\text {real }}\right)=\sqrt{\sum\left(\mathrm{x}_{\text {predict }}-\mathrm{x}_{\text {real }}\right)^{2}}
$$

The SPPMCC returns $\mathrm{R}^{2}$, which is the square of this correlation coefficient. An $\mathrm{R}^{2}$ of 1 indicates that the regression line perfectly fits the data.

\section{RESULTS AND DISCUSSION}

The ANFIS models are trained by 100 input-output datasets of STS, EM and CS and tested and verified by 22 datasets. Moreover up to 2500 epochs is specified for training process to guarantee the reaching the minimum error. According to the training results, the models reach to the minimum error size after 400 epochs, however 2500 epochs confirm the ultimate possible convergence in the model. Fig. 6 shows the training process of input data to establish a fuzzy relationship between splitting tensile strength, modulus of elasticity and compressive strength of LWSCC. 
Figs. 7(a, b) show the comparison of the predicted and empirical values of CS. Fig. 7a shows the real input values of CS versus FIS prediction, since the training error size is very small; therefore the predicted values are in good compatibility with the real experimental values. To ensure the efficiency of the training process, about $20 \%$ of whole data is utilized to test the established relationship. Fig. 7 (b) shows the analysis result of the testing data. It is clear that majority of the predicted values are in good compatibility with the predicted values. There is just a considerable difference between the empirical and predicted CS value in the last dataset of testing data.

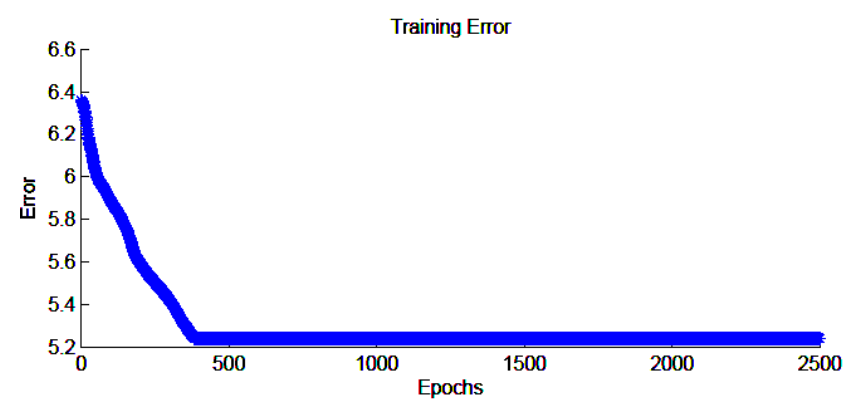

Fig. 6: Training of data to establish a fuzzy based relation between input and target data

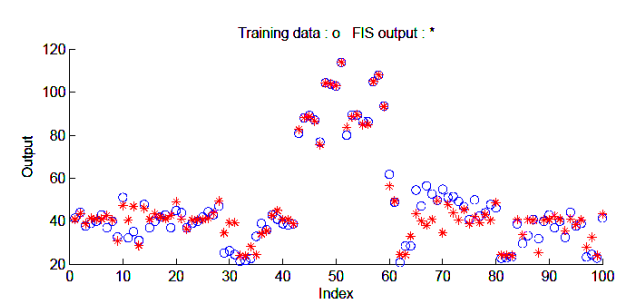

(a)

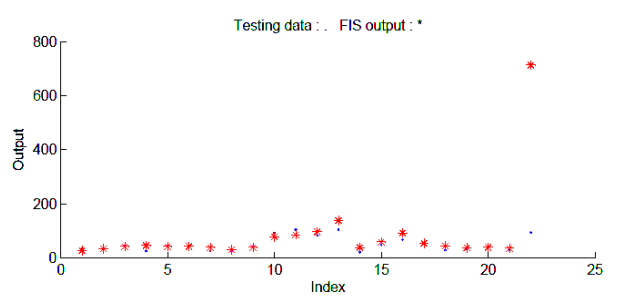

(b)

Fig 7. a) Compatibility of given CS vs. FIS predicted CS, b) testing the results of established FIS model

Fig. 8 gives a better 3D view of the developed FIS model between STS, EM and CS. 


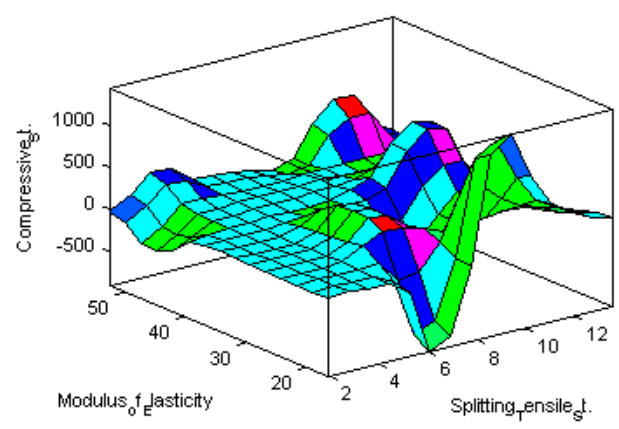

Fig. 8: 3-D view of relation between STS, EM and CS in ANFIS model

To evaluate the developed FIS model, regression analysis is performed to find a best matching multi-factor linear relationship between compressive strength, modulus of elasticity and splitting tensile strength as shown in Eq. (4). According to the statistical coefficients of Eq. (4) in Table 2, the proposed model in regression analysis has a good compatibility with the empirical data.

$$
\begin{array}{cccc}
\mathrm{CS}=\alpha . \mathrm{STS}+\beta . \mathrm{EM}+\gamma & \boldsymbol{\alpha} & \boldsymbol{\beta} & \boldsymbol{\gamma} \\
\cline { 2 - 4 } & 6.129635 & 1.21536 & -12.3031
\end{array}
$$

Table 2. Statistical coefficients of the model in regression analysis

\begin{tabular}{|c|c|c|c|c|}
\hline Coefficient & Multiple R & R Square & Adjusted R Square & Standard Error \\
\hline Value & 0.919434 & 0.845359 & 0.842138 & 9.015084 \\
\hline
\end{tabular}

To verify the developed model in ANFIS model, Fig. 9 compares the CS values predicted by ANFIS and regression analysis with the real empirical data of this study.

It shows a good compatibility between the models and the real data; however in the majority of plotted data, ANFIS model predicts CS values vary close and adjacent to the empirical data. 


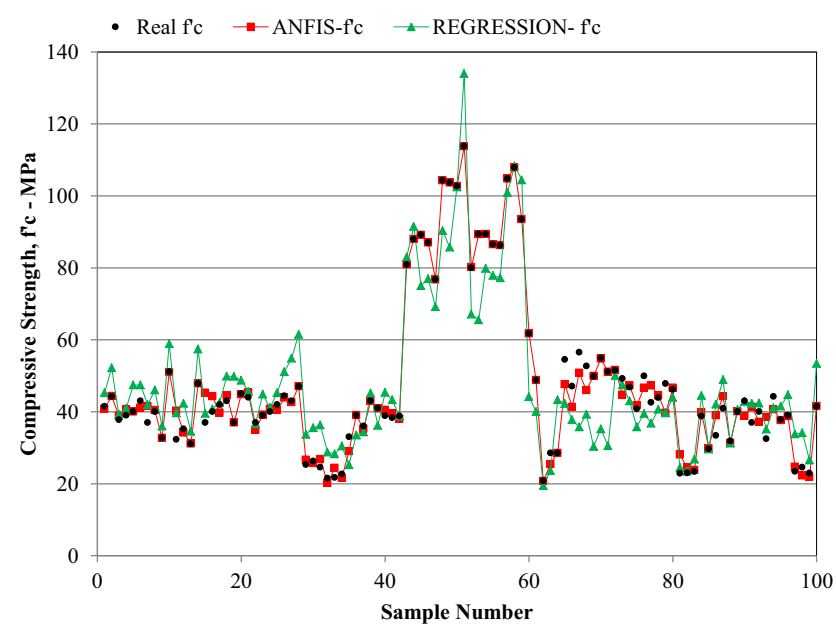

Fig. 9. Comparing the empirical data of CS vs. predictions of ANFIS and regression analysis

To better understanding of the efficiency of the developed models, compatibility of the predicted values with the empirical data is evaluated by EN and SPPMCC coefficients.

Table 3 shows the values of these coefficients by comparing the predictions of ANFIS and regression model with the empirical data respectively.

Table 3. Mathematical evaluation coefficients of developed models

\begin{tabular}{|c|c|c|}
\hline Model & EN & SPPMCC \\
\hline ANFIS & 26.432 & 0.986165 \\
\hline Multi factor linear regression & 88.4 & 0.845359 \\
\hline
\end{tabular}

Figs. 10(a, b) plot the predicted CS values vs. empirical data in ANFIS and regression analysis respectively. 

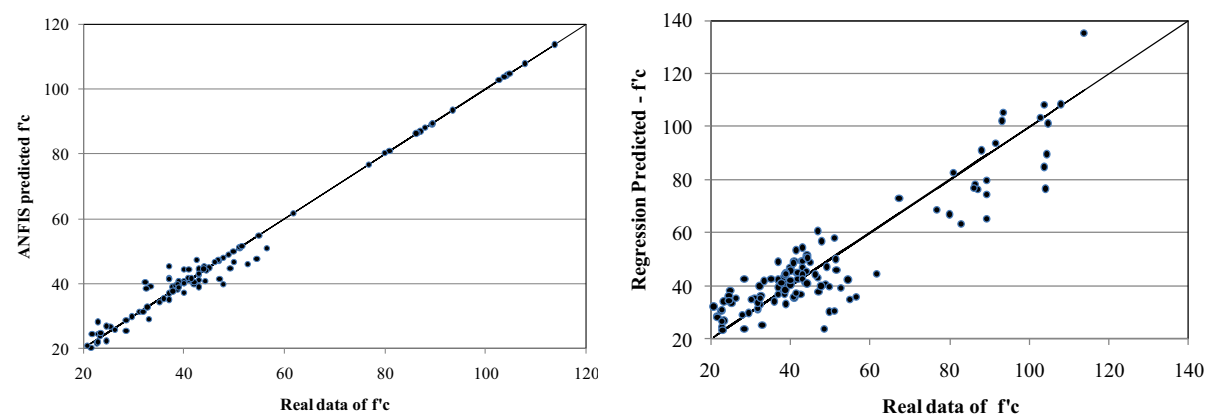

Fig. 10. Comparison of real given data of CS vs. prediction of a) ANFIS, b) Regression analysis

According to Table 3 and Figs 11( $a, b)$ it is obvious that the ANFIS model is more compatible with the empirical data and is recommended to estimate compressive strength from combination of splitting tensile strength and modulus of elasticity. Furthermore the good estimating established model in regression analysis confirms the efficiency of the ANFIS model.

The non-linear structural and technological behavior of self-compacting and light weight concrete is not understood very well in the literature.

Consequently combination of these two concretes in LWSCC makes the behavior more complicated. Since the intelligent based models are always better than tradition models in dealing with any types of data with unknown distribution, the ANFIS model in this study gives more reasonable predictions than regression analysis.

\section{CONCLUSION}

This study utilizes the intelligent based ANFIS to develop a model to predict the 28 days CS from combination of STS and EM in LWSCC. In addition a model developed by multi factor regression analysis is proposed to verify the ANFIS Model.

LWSCC is a new construction material and the published experimental investigations are very rare in the literature. However to have the most comprehensive data so far, this study collected the data from 24 recently published experimental investigations:

- Comparing all the features in ANFIS architecture, Sugento type structure, bell shaped membership function and hybrid optimization method is applied to develop the FIS model.

- The model in ANFIS well predicts the CS value from combination of EM and STS. 
- The model proposed by multi factor linear regression analysis also gives a reasonable prediction of CS.

- Evaluating the compatibility of the predictions of both models with empirical data by EN and SPPMCC statistical coefficients, the predictions of ANFIS model is more compatible and adjacent to the empirical data since it has the least error and the highest correlation factor.

- ANFIS models are recommended to investigate the relationship between fresh and hardened properties of non-linear complicated materials like LWSCC.

\section{REFERENCES}

1. M. Imam, L. Vandewalle, F. Mortelmans, "Are current concrete strength tests suitable for high strength concrete?", Materials and Structures 28: 384-391, 1995.

2. P. Bamforth, D. Chisholm, J. Gibbs and T. Harris, "Properties of Concrete for use in Euro code 2", The Concrete Centre, UK, 2008.

3. B. Vakhshouri, S. Nejadi, "Application of Adaptive Neuro-Fuzzy Inference System in High Strength Concrete", International Journal of Computer Applications 101(5): 39-48, 2014.

4. L. Naderloo, R. Alimardani, M. Omid, F. Sarmadian, P. Javadikia, M.Y. Torabi, F. Alimardani, “Application of ANFIS to predict crop yield based on different energy inputs", Measurement 45: 1406-1413, 2012.

5. M.C. Nataraja, M.A. Jayaram, C.N. Ravikumar, A fuzzy-neuro model for normal concrete mix design”, Engineering Letters, 13(2): 98-107, 2006.

6. S. Tesfamariam, H. Najjaran, "Adaptive network-fuzzy inferencing to estimate concrete strength using mix design”, Journal of Materials in Civil Engineering, 19(7): 550-560, 2007.

7. M. Bilgehan, "Comparison of ANFIS and NN models with a study in critical buckling load estimation", Nondestructive Testing and Evaluation, 26(1): 35-55, 2011.

8. H. Tanyildizi and A. Coşkun, "Fuzzy logic model for prediction of compressive strength of light weight concrete made with Scoria aggregate and fly ash", International Earthquake Symposium Kocaeli, Turkey, 2226 October, 2007.

9. T. Uyunoglu, O. Unal, "A new approach to determination of compressive strength of fly ash concrete using fuzzy logic”, Journal of Scientific and Industrial Research, 65: 894-899, 2006.

10. F.A. Barrios Illidge, "Acoustic emission techniques and cyclic load testing load testing for integrity evaluation of self-compacting normal and self-compacting", PhD thesis. University of South Carolina, USA, 2010.

11. Y.J. Kim, Y.W. Choi, M. Lachemi, "Characteristics of self-consolidating concrete using two types of lightweight coarse aggregates", Construction and Building Materials, 24(1): 11-16, 2010.

12. E. Guneyisi, M. Gesoglu, E. Booya, "Fresh properties of self-compacting cold bonded fly ash lightweight aggregate concrete with different mineral admixtures", Materials and Structures, 45(12): 1849-1859, 2012.

13. O. Andic Cakır, E. Yogurtcu, S. Yazıc1, K. Ramyar, "Self-compacting lightweight aggregate concrete: design and experimental study", Magazine of Concrete Research, 61(7): 519-527, 2009.

14. H. Mazaheripour, S. Ghanbarpour, S.H. Mirmoradi, I. Hosseinpour, "The effect of polypropylene fibers on the properties of fresh and hardened lightweight self-compacting concrete", Construction and Building Materials, 25(1): 351-358, 2011.

15. P.L. Domone, "Self-compacting concrete: An analysis of 11 years of case studies", Cement and Concrete Composites, 28(2): 197-208, 2006.

16. F.M. Almeida Filho, B.E. Barragan, J.R. Casas, A.L.H.C. El Debs, "Hardened properties of self-compacting concrete - A statistical approach", Construction and Building Materials, 24(9): 1608-1615, 2010.

17. J. Alexandre Bogas, A. Gomes, M.F.C. Pereira, "Self-compacting lightweight concrete produced with expanded clay aggregate", Construction and Building Materials, 35:1013-1022, 2012.

18. M.S. Anwar, A.W. Pramono, V.I. Judarta, A. Manaf, "The role of pumice in self-compacting lightweight aggregate concrete manufacture", Asian Transactions on Basic and Applied Sciences (ATBAS), 2(4): $14-20,2012$. 
19. G. Pons, M. Mouret, M. Alcantara, J. L. Granju, "Mechanical behavior of self-compacting concrete with hybrid fiber reinforcement", Materials and Structures, 40(2): 201-210, 2007.

20. T.S. Babu, M.V. Seshagiri, R.D. Rama, "Mechanical properties and stress-strain behavior of self-compacting concrete with and without glass fibers", Asian Journal of Civil Engineering (Building and Housing), 9(5): $457-472,2008$

21. O. Gencel, C. Ozel, W. Brostow and G. Martı'nez-Barrera, "Mechanical properties of self-compacting concrete reinforced with polypropylene fibers", Materials Research Innovations, 15(3): 216-225, 2011.

22. S.K. Ghosh, "High strength concrete in U.S codes and standards", XIV Congreso Nacional de Ingeniería Estructural, 1-16, Acapulco, Gro, 2004.

23. E. Joelianto, B. Rahmat, "Adaptive Neuro Fuzzy Inference System (ANFIS) with Error Back propagation Algorithm using Mapping Function”, International journal of artificial intelligence, 1(A08), 2008.

24. C. Ozel, "prediction of compressive strength of concrete from volume ratio and Bingham parameters using adaptive neuro-fuzzy inference system (ANFIS) and data mining", International Journal of Physical sciences, 6(31): 7078-7094, 2011.

25. A. Sadrmomtazi, J. Sobhani, M.A. Mirgozar, "Modeling compressive strength of EPS lightweight concrete using regression, neural network and ANFIS", Construction and Building Materials 42: 205-216, 2013.

26. J. Sobhani, M. Najimi, A.R. Pourkhorshidi, T. Parhizkar, "Prediction of the compressive strength of no-slump concrete: A comparative study of regression, neural network and ANFIS models", Construction and Building Materials, 24: 709-718, 2010.

27. K. Kobayashi, "Characteristics of self-compacting concrete in fresh state with artificial light-weight aggregate", Japanese Society of material science, 50(9): 1021-1027, 2001.

28. C. Shi, Y. Wu, "Mixture proportioning and properties of self-consolidating lightweight concrete containing glass powder", ACI Materials Journal, 102(5): 355-363, 2005.

29. C.L. Hwang, M.F. Hung, "Durability design and performance of self-consolidating lightweight concrete", Construction and building materials, 19: 619-626, 2005.

30. B. Persson, "On the internal frost resistance of self-compacting concrete, with and without polypropylene fibers. Materials and Structures", 39: 707-716, 2006.

31. M. Hubertova, R. Hela, "The Effect of metakaolin and silica fume on the properties of lightweight self-consolidating concrete", ACI publication; SP-243(3): 35-48, 2007.

32. B.Z. Dymond, "Shear strength of a PCBT-53 girder fabricated with lightweight, Self-consolidating concrete", Master's thesis, Virginia Polytechnic Institute and State University, 2007.

33. D. Ward, "Performance of prestressed double-tee beams cast with lightweight self-consolidating concrete", Master's thesis, University of Arkansas, USA, 2010

34. W.H. Yung, "Durability of self-consolidating lightweight aggregate concrete using dredged silt", Construction and building materials, 23: 2332-2337, 2009

35. A.A. Maghsoudi, S.H. Mohamadpour, M. Maghsoudi, "Mix design and mechanical properties of selfcompacting light weight concrete", International J. of Civil engineering, 9(3): 230-236, 2011.

36. J. Bymaster, "Prestress losses in lightweight self-consolidating concrete", Master thesis, University of Arkansas, USA, 2012.

37. M. Kaffetzakis, C. Papanicolaou, "Mix Proportioning method for lightweight aggregate SCC (LWASCC) based on the optimum picking point concept", Innovative Materials and Techniques in Concrete Construction, pp 131-151, 2012.

38. O. Andiç-Çakır, S. Hızal, Influence of elevated temperatures on the mechanical properties and microstructure of self- consolidating lightweight aggregate concrete, Construction and building materials, 34: 575-583, 2012.

39. S. Juradin, G. Baloevi'c, A. Harapin, "Experimental testing of the effects of fine particles on the properties of the self-compacting lightweight concrete", Advances in Materials Science and Engineering, 2012: 1-8, 2012

40. M.N. Soutsos, G. Turuallo, K. Owens, J. Kwasny, S.J. Barnett, P.A.M. Basheer, "Maturity testing of lightweight self-compacting and vibrated concretes", Construction and building materials, 47: 118-125, 2013. 


\section{LIST OF FIGURES AND TABLES:}

Fig. 1. Architecture of simulated model in ANFIS

Rys. 1. Architektura modelu symulowanego w ANFIS

Fig. 2. General form of ANFIS operation between input and output data

Rys. 2. Ogólny sposób funkcjonowania ANFIS od zmiennych wejściowych do wyjściowych

Fig. 3. mf plots of a) STS and b) EM in training process of data to establish the fuzzy logical relation

Rys. 3. Wykresy mf a) STS i b) EM w procesie treningu w celu utworzenia zależności na podstawie rozmytych reguł logicznych

Fig. 4. Reasoning scheme (if-then rules; if input 1 and input 2 then output) of NAFIS with bell shaped $\mathrm{mf}$ Rys. 4. Schemat wnioskowania (zasady jeśli-to; jeśli wartość wejściowa 1 i wartość wejściowa 2 to wynik) NAFIS dla funkcji przynależności w kształcie dzwonu

Fig. 5. Testing and training data range in ANFIS model and regression analysis

Rys. 5. Zakres danych testowych i treningowych w modelu ANFIS oraz w analizie regresji

Fig. 6. Training of data to establish a fuzzy based relation between input and target data

Rys. 6. Trening w celu utworzenia zależności na podstawie rozmytych reguł logicznych pomiędzy danymi wejściowymi i docelowymi

Fig 7. a) Compatibility of given CS vs. FIS predicted CS, b) testing the results of the established FIS relation

Fig 7. a) Kompatybilność danego CS z CS predykcyjnym z FIS, b) testowanie wyników otrzymanej zależności FIS

Fig. 8. 3-D view of relation between STS, EM and CS in ANFIS model

Rys. 8. Widok 3D zależności pomiędzy STS, EM i CS w modelu ANFIS

Fig. 9. Comparing the empirical data of CS vs. predictions of ANFIS and regression analysis

Rys. 9. Porównanie danych empirycznych z CS z predykcjami z ANFIS i analizy regresji

Fig. 10. Comparison of real given data of CS vs. prediction of a) ANFIS, b) Regression analysis

Rys. 10. Porównanie faktycznych danych z CS z danymi predykcyjnymi z a) ANFIS, b) z analizy regresji

Table 1. Data base for mix design of LWSCC

Tabela 1. Baza danych dla składu LWSCC

Table 2. Statistical coefficients of the model in regression analysis

Tabela 2. Współczynniki statystyczne modelu $\mathrm{w}$ analizie regresji

Table 3. Mathematical evaluation coefficients of developed models

Tabela 3. Współczynniki oceny matematycznej wypracowanych modeli 


\section{PREDYKCJA WYTRZYMALOŚCI NA ŚCISKANIE LEKKIEGO BETONU SAMOUSZCZELNIAJĄCEGO WG MODELU ANALITYCZNEGO ANFIS}

Slowa kluczowe: ANFIS, analiza regresji, lekki beton samouszczelniający, wytrzymałość na ściskanie, moduł sprężystości, wytrzymałość na rozciąganie.

\section{STRESZCZENIE:}

Lekki beton samouszczelniający (LWSCC) to połączenie betonu lekkiego (LWC) i samouszczelniającego (SCC) i posiada zarówno zalety, jak i wady obu typów betonu. Ze względu na złożony charakter i nieliniowe zachowanie LWSCC oraz dużą liczbę parametrów, które mają wpływ na wyniki analiz, tradycyjne metody mogą okazać się niewystarczające do określenia współzależności pomiędzy różnymi właściwościami LWSCC; jakkolwiek model ANFIS okazał się skuteczny, jeśli chodzi o określanie zależności pomiędzy parametrami w przypadku złożonych systemów technologicznych oraz materiałów. W opracowaniu wykorzystano znaczącą ilość danych eksperymentalnych, dotyczących tego nowego materiału budowlanego, w celu przeanalizowania zależności pomiędzy wytrzymałością na ściskanie (CS), wytrzymałością na rozciąganie (STS) oraz modułem sprężystości (EM). Dodatkowo, opracowano nowy model analityczny w ramach systemu rozmytego, który został też zweryfikowany przy pomocy zgromadzonych danych, jak również analizy regresji wieloczynnikowej. Zgromadzone dane umożliwiają także porównanie otrzymanych proporcji mieszanki LWSCC. Ponieważ w literaturze nie pojawily się dotąd wskazówki w tym zakresie, porównanie takie może stać się doskonałym punktem wyjścia dla dalszych badań na temat właściwości LWSCC oraz składu mieszanki. Porównując wszystkie cechy charakterystyczne przy pomocy modelu ANFIS, opracowano model FIS przy zastosowaniu strukturę typu Sugento, funkcję przynależności w kształcie dzwonu oraz metodę optymalizacji hybrydowej. Zależność pomiędzy danymi jednowynikowymi (CS) i dwuwynikowymi (STS, EM), pozyskaną za pomocą modelu ANFIS, prezentuje rys. 1 .

(a)
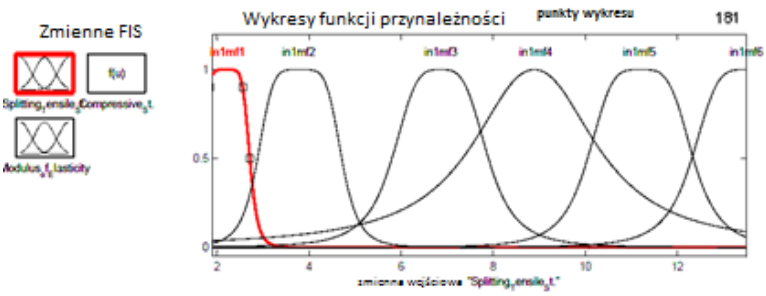

(b)

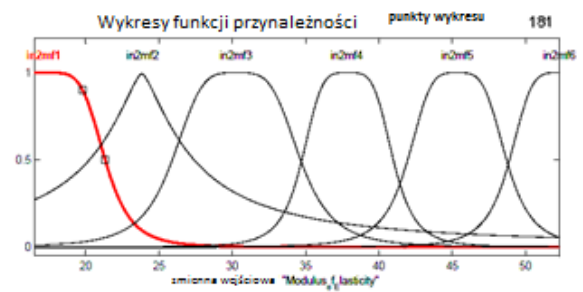

Rys. 1. Ogólny sposób funkcjonowania ANFIS od zmiennych wejściowych do wyjściowych 
Aby zapewnić efektywność procesu treningowego, około $20 \%$ całości danych wykorzystuje się do przetestowania utworzonej zależności. Rys. 2 (a, b) przedstawiają porównanie wartości predykcyjnych i empirycznych CS w procesie treningu i testowania.

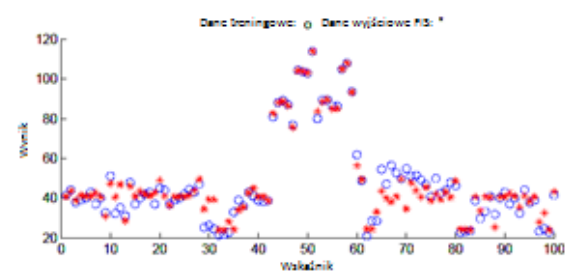

(a)

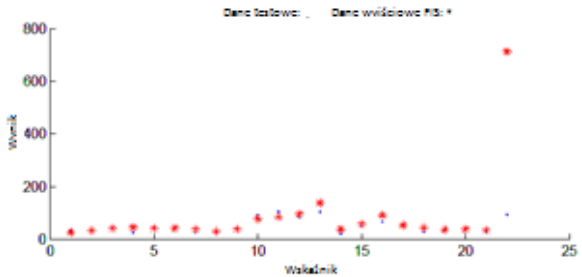

(b)

Rys. 2. a) Kompatybilność danej wartości CS z wartością predykcyjną CS z FIS, b) testowanie wyników utworzonego modelu FIS

Tabela 1 przedstawia porównanie predykcji z modelu ANFIS oraz $\mathrm{z}$ analizy regresji $\mathrm{z}$ danymi empirycznymi, bazującymi odpowiednio na normie euklidesowej (EN) oraz na kwadracie współczynnika korelacji iloczynu momentów Pearsona (SPPMCC).

Tabela 1. Matematyczne wskaźniki oceny dla opracowanym modeli

\begin{tabular}{|c|c|c|}
\hline Model & EN & SPPMCC \\
\hline ANFIS & 26.432 & 0.986165 \\
\hline Wieloczynnikowa regresja liniowa & 88.4 & 0.845359 \\
\hline
\end{tabular}

Rys. $3(\mathrm{a}, \mathrm{b})$ przedstawiają predykcyjne wartości CS oraz dane empiryczne pochodzące odpowiednio z modelu ANFIS oraz $\mathrm{z}$ analizy regresji.
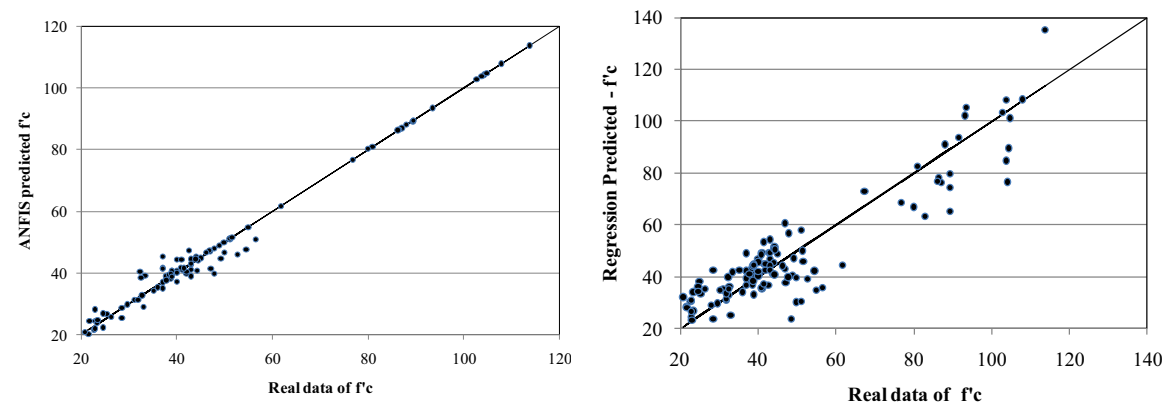

Rys. 3. Porównanie faktycznych danych z CS oraz danych predykcyjnych z a) ANFIS, b) analizy regresji 


\section{Uwagi końcowe}

- Model ANFIS pozwala precyzyjnie przewidzieć wartość CS na podstawie kombinacji EM i STS.

- Model analizy wieloczynnikowej regresji liniowej także pozwala na efektywną predykcję CS.

- Model ANFIS jest w większym stopniu kompatybilny i przystający do danych empirycznych ze względu na najniższą ilość błędów oraz najwyższy współczynnik korelacji. 